\title{
Overexpression of appoptosin promotes mitochondrial damage in MIN6 cells
}

\author{
TIANXI WANG ${ }^{1}$, WENJING WEI ${ }^{1}$, HUSSEN AMIR AHMED MANSAI ${ }^{1}$, CAOXIN HUANG $^{1}$, LONG LI $^{1}$, \\ QIUHONG YE ${ }^{1}$, HONGYAN YIN $^{1}$, CHEN YANG $^{1}$, XUEJUN LI $^{1,2}$, SUHUAN LIU $^{1,3}$ and SHUYU YANG ${ }^{1,2}$ \\ ${ }^{1}$ Xiamen Diabetes Institute, The First Affiliated Hospital of Xiamen University, Xiamen, Fujian 361003; \\ ${ }^{2}$ Department of Endocrinology and Diabetes; ${ }^{3}$ Central Laboratory, The First Affiliated Hospital of \\ Xiamen University, Xiamen, Fujian 361003, P.R. China
}

Received April 14, 2017; Accepted September 12, 2017

DOI: $10.3892 / \mathrm{mmr} .2018 .8759$

\begin{abstract}
Damage to pancreatic $\beta$-cells is closely associated with diabetes. However, the mechanism underlying injury to pancreatic $\beta$-cells remains unclear, although hypoxia is considered as one of the leading causes. Appoptosin is a mitochondrial protein that promotes neuronal apoptosis. Studies conducted on appoptosin thus far have primarily focused on Alzheimer's disease, and have demonstrated that the expression of appoptosin is significantly increased in ischemic-reperfused rat brains, which indicates its close association with hypoxia. However, the role of appoptosin in pancreatic $\beta$-cells, which are sensitive to hypoxia, remains unknown. Therefore, the current study aimed to investigate the function of appoptosin in pancreatic $\beta$-cells in a hypoxic environment. Cobalt chloride $\left(\mathrm{CoCl}_{2}\right)$ was used to mimic the hypoxic status of the cells. The results of a terminal deoxynucleotidyl transferase dUTP nick-end labeling assay demonstrated that $\mathrm{CoCl}_{2}$ promoted apoptosis in MIN6 mouse insulinoma cells, and western blotting and reverse transcription-quantitative polymerase chain reaction results demonstrated that the activation of appoptosin was induced, promoting mitochondrial damage and caspase 3 activation. Silencing of appoptosin using short hairpin RNA significantly reduced $\mathrm{CoCl}_{2}$-induced apoptosis in MIN6 cells. In conclusion, $\mathrm{CoCl}_{2}$ increased the expression of appoptosin, which aggravated mitochondrial damage in MIN6 cells. Therefore, inhibiting the expression of appoptosin may benefit pancreatic $\beta$-cells survival during islet transplantation.
\end{abstract}

\section{Introduction}

Diabetes is a common chronic disease worldwide. Along with rapid economic development, the incidence of diabetes in

Correspondence to: Dr Shuyu Yang or Dr Suhuan Liu, Xiamen Diabetes Institute, The First Affiliated Hospital of Xiamen University, 55 Zhenhai Road, Xiamen, Fujian 361003, P.R. China E-mail: xmyangshuyu@126.com

E-mail: liush_xm@126.com

Key words: apoptosis, appoptosin
China has rapidly increased $(1,2)$. Type 1 diabetes is usually caused by damage to pancreatic $\beta$-cells and insufficient secretion of insulin (3). To date, treatments targeting type 1 diabetes have not promised a complete cure. Advanced techniques such as islet transplantation may be available in the near future for treating type 1 diabetes (4-6). However, a drawback of this technique is that a large number of pancreatic $\beta$-cells undergo apoptosis owing to hypoxia $(7,8)$. A recent report indicated that diet cycles that mimic fasting in animal models may successfully promote $\beta$-cell regeneration (9). However, the effect of diet therapy that mimics fasting in humans remains unknown. Reducing the rate of apoptosis of pancreatic $\beta$-cells may be a primary target in the treatment of patients with type 1 diabetes.

Appoptosin, encoded by SLC25A38, is a novel proapoptotic protein located in the inner membrane of mitochondria $(10,11)$. It is strongly expressed in the brain cells of patients with Alzheimer's disease, and it has been identified to interact with the amyloid precursor protein (12). Studies have demonstrated that, in vitro, the overexpression of appoptosin promotes apoptosis in neuronal and $293 \mathrm{~T}$ cells, accompanied by mitochondrial fusion $(10,13)$. In vivo murine studies have also demonstrated that overexpression of appoptosin was detected in the brains of ischemia-reperfused rats (10). To the best of our knowledge, no previous studies have investigated the role of appoptosin in diabetes and pancreatic $\beta$-cells. Therefore, the present study investigated the role of appoptosin in MIN6 cells.

Cobalt chloride $\left(\mathrm{CoCl}_{2}\right)$ has been previously used to mimic hypoxia and induce cell apoptosis $(14,15)$. Cobalt inhibits prolyl hydrolase domain (PHD) enzymes (oxygen sensors) by replacing iron, making these enzymes unable to mark hypoxia inducible factor (HIF)-1 $\alpha$ for degradation (16). Dimethyloxaloylglycine (DMOG) and 1,4-dihydrophenonthrolin-4-1-3-carboxylic acid (1,4-DPCA) are both cell permeable, competitive inhibitors of PHDs and HIF-prolyl hydroxylases (HIF-PHs). They are able to stabilize HIF-1 $\alpha$ efficiently at normal oxygen tensions in vitro (17-22). In the present study, the results demonstrated that $400 \mu \mathrm{M} \mathrm{CoCl}_{2}$ induced apoptosis in MIN6 cells and considerably reduced cell viability. In addition, overexpression of appoptosin in MIN6 cells increased caspase 3 activity and mitochondrial damage. By contrast, inhibition of appoptosin by short hairpin (sh)RNA partially restored the viability of MIN6 cells exposed to hypoxia. Therefore, as overexpression 
of appoptosin increased mitochondrial damage and cell apoptosis, inhibiting the expression of appoptosin may reduce islet apoptosis during islet transplantation and may provide a novel strategy for the care of patients with diabetes.

\section{Materials and methods}

Cell culture and transfection. MIN6 cells (American Type Culture Collection, Manassas, VA, USA) were cultured in high glucose Dulbecco's modified Eagle's medium (DMEM; Gibco; Thermo Fisher Scientific, Inc., Waltham, MA, USA) with $1 \%$ penicillin-streptomycin (GE Healthcare, Chicago, IL, USA) and $15 \%$ fetal bovine serum (FBS; Gibco; Thermo Fisher Scientific, Inc.) (23). Detailed information regarding the siRNA sequence has been described in a previous study (10). The siRNA and negative control siRNA were synthesized and provided by Invitrogen (Thermo Fisher Scientific, Inc.). The siRNA targeting sequence of appoptosin was as follows: AGA CGCTCATGTTACACCCAGTGAT (10). Overexpression appoptosin plasmids were transfected into MIN6 cells by using Lipofectamine ${ }^{\circledR} 3000$ (Invitrogen; Thermo Fisher Scientific, Inc.). Overexpression Appoptosin plasmids were constructed using pCMV-Myc as described (11). Lipofectamine ${ }^{\circledR} 3000$ was used according to the manufacturer's protocols. A brief protocol for the transfection is as follows: Firstly, $4 \mu \mathrm{g}$ plasmid was addition to $500 \mu \mathrm{l}$ DMEM. Then, $12 \mu \mathrm{l}$ Lipofectamine ${ }^{\circledR} 3000$ was added. Lastly, the mixture was kept at room temperature for $10 \mathrm{~min}$ and then added to one well of a six-well plate. Construction of the overexpression plasmids were conducted as described (11). pCMV-Myc plasmids served as the control.

Briefly, in the present study, $1 \times 10^{6}$ MIN6 cells were seeded in 6-well plates overnight prior to $\mathrm{CoCl}_{2}, \mathrm{DMOG}, \mathrm{H}_{2} \mathrm{O}_{2}$ and 1,4-DPCA treatment. Then, $400 \mu \mathrm{M} \mathrm{CoCl}_{2}$ (Sigma-Aldrich; Merck KGaA, Darmstadt, Germany), $100 \mu \mathrm{M} \mathrm{H}_{2} \mathrm{O}_{2}$ (Sigma-Aldrich Merck KGaA), $1 \mathrm{mM}$ DMOG and $100 \mu \mathrm{M}$ 1,4-DPCA (both Selleck Chemicals, Shanghai, China) were added to the plates containing MIN6 cells (90\% fusion). Finally, the cells were collected and/or lysed according to the guidance of following experiments. $\mathrm{CoCl}_{2}$ was dissolve in cell culture medium (DMEM) to a concentration of $400 \mathrm{mM} . \mathrm{H}_{2} \mathrm{O}_{2}$ $(100 \mu \mathrm{M})$ were diluted by the medium prior to experimentation. DMOG $(1 \mathrm{mM})$ and 1,4-DPCA $(100 \mu \mathrm{M})$ were dissolved in $0.1 \%$ DMSO. $0.1 \%$ DMSO served as the control in experiment containing DMOG and 1,4-DPCA.

Terminal deoxynucleotidyl transferase dUTP nick-end labeling (TUNEL) assay and cell viability. Cells $\left(2 \times 10^{5}\right)$ were plated in 24-well plates overnight and cultured in an incubator at $37^{\circ} \mathrm{C}$ prior to the experiment. MIN6 cells were washed in precooled 0.01 M PBS three times. Fresh 4\% paraformaldehyde was used to fix the cells for $10 \mathrm{~min}$ at room temperature, after which the cells were permeabilized with $0.1 \%$ Triton-X 100 in $0.01 \mathrm{M}$ PBS for $15 \mathrm{~min}$ at room temperature. Subsequently, TUNEL (Roche Diagnostics, Indianapolis, IN, USA) staining reagents were added and the cells were incubated at $37^{\circ} \mathrm{C}$ in the dark for $1 \mathrm{~h}$. Finally, the cell nuclei were stained using DAPI $(0.3 \mathrm{mM})$ for $3 \mathrm{~min}$ at room temperature and washed with $0.01 \mathrm{M}$ PBS three times. The number of TUNEL-positive cells was determined using ImageJ software (Java 1.8.0_112, National Institutes of Health, Bethesda, MD, USA). A total of 5 fields per view were observed with a fluorescent microscope; the excitation wavelength applied was $555 \mathrm{~nm}$. A Cell Counting Kit-8 (CCK-8; Dojindo Molecular Technologies, Inc., Kumamoto, Japan) was used to quantify viable MIN6 cells following $400 \mu \mathrm{M} \mathrm{CoCl}_{2}$ treatment with or without siRNA knockdown of appoptosin, according to the manufacturer's protocol. MIN6 cells $\left(1.5 \times 10^{4}\right)$ were seeded in 96-well plates and cultured in an incubator at $37^{\circ} \mathrm{C}$ overnight.

Immunofluorescence and JC-1 staining. Cells $\left(2 \times 10^{5}\right)$ were plated in 24-well plates overnight and cultured in an incubator at $37^{\circ} \mathrm{C}$ prior to the experiment. MIN6 cells were washed in precooled 0.01 M PBS three times. Fresh 4\% paraformaldehyde was used to fix the cells for $10 \mathrm{~min}$ at room temperature. Subsequently, the cells were permeabilized with $0.1 \%$ Triton-X 100 in $0.01 \mathrm{M}$ PBS for $15 \mathrm{~min}$ at room temperature. Primary antibody appoptosin (cat. no. sc-515883; Santa Cruz Biotechnology, Inc., Dallas, TX, USA) and cleaved-caspase 3 (cat. no. 9661; Cell Signaling Technology, Inc., Danvers, MA, USA) were diluted to one hundred. Goat anti-rabbit IgG (Alexa Fluor $^{\circledR}$ 488; cat. no. A-11034; Thermo Fisher Scientific, Inc.) and Goat anti-mouse IgG (Alexa Fluor ${ }^{\circledR}$ 594; cat. no. A-11020; Thermo Fisher Scientific, Inc.) were used as the secondary antibodies, which were diluted to one thousand. The detailed protocol of immunofluorescence has been described in our previous study (24). In brief, $10 \mu \mathrm{M} \mathrm{JC}-1$ (Invitrogen; Thermo Fisher Scientific, Inc.) and $2 \mu \mathrm{g} / \mathrm{ml}$ Hoechst reagent (Guangzhou RiboBio Co., Ltd., Guangzhou, China) were added to MIN6 cells (90\% fusion) for $10 \mathrm{~min}$ at $37^{\circ} \mathrm{C}$ at the same time. Cells were subsequently washed with warm DMEM. Finally, the stained cells were cultured in warm DMEM containing 10\% FBS for live cell imaging (Confocal microscope FV1000; Olympus Corp., Tokyo, Japan).

Western blot analysis. MIN6 cells transfected with pCMV (empty vector) and overexpression vector were lysed using radioimmunoprecipitation assay buffer (EMD Millipore, Billerica, MA, USA). The concentration of protein in each sample was determined using a bicinchoninic acid kit (Thermo Fisher Scientific, Inc.). The lysates and loading buffer were mixed and boiled for $10 \mathrm{~min}$. Subsequently, lysates (30 $\mu \mathrm{g}$ total protein) were loaded onto $10 \%$ SDS-PAGE gels, which were subjected to electrophoresis and the proteins were transferred onto polyvinylidene difluoride (PVDF) membranes (EMD Millipore). The PVDF membrane was blocked with 5\% non-fat milk (Cell Signaling Technology, Inc. USA) for $60 \mathrm{~min}$ at room temperature. The primary antibodies against cleaved-caspase 3 (cat. no. 9661, Cell Signaling Technology, Inc.), a-tubulin (cat. no. sc-5546, Santa Cruz Biotechnology, Inc.), appoptosin (cat. no. PA5-42472, Thermo Fisher Scientific, Inc.) and HIF-1a (cat. no. NB100-479, Novus Biologicals, LLC, Littleton, CO, USA) were diluted to 1:1,000 and incubated with membranes. The secondary antibodies (Sigma-Aldrich; Merck KGaA) and enhanced chemiluminescence (ECL detection substrate) reagent (Xiamen Lulong Biotech Co., Ltd., Xiamen, China) were added to the membranes. Anti-rabbit IgG (1:5,000; cat. no. 31460; Thermo Fisher Scientific, Inc.) and anti-mouse IgG (1:5,000; cat. no. 31430; Thermo Fisher Scientific, Inc.), horseradish peroxidase (HRP) conjugated antibody was used as the secondary antibody. The signal was captured 

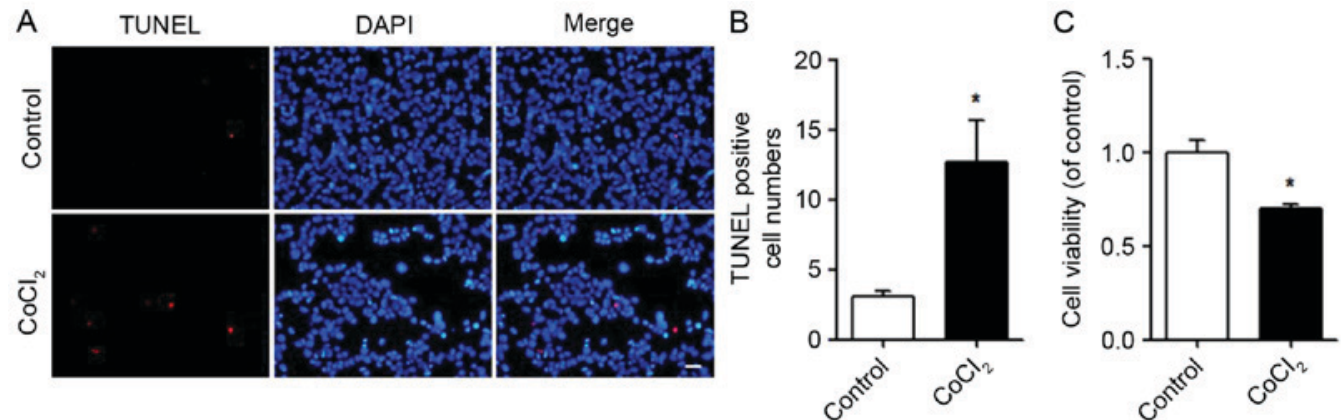

Figure 1. $\mathrm{CoCl}_{2}$ induces apoptosis of MIN6 cells. A total of $400 \mu \mathrm{M} \mathrm{CoCl}_{2}$ was used to treat MIN6 cells for $24 \mathrm{~h}$. (A) Representative images of TUNEL staining in control and $\mathrm{CoCl}_{2}$ groups. Magnification, $\mathrm{x} 400$. Scale bar=20 $\mu \mathrm{m}$. (B) Quantification of the number of TUNEL-positive cells. (C) Cell viability was determined in the control and $\mathrm{CoCl}_{2}$ groups. Each experiment was repeated three times. ${ }^{*} \mathrm{P}<0.05$ vs. control group. $\mathrm{CoCl}_{2}$, cobalt chloride; TUNEL, terminal deoxynucleotidyl transferase dUTP nick-end labeling.
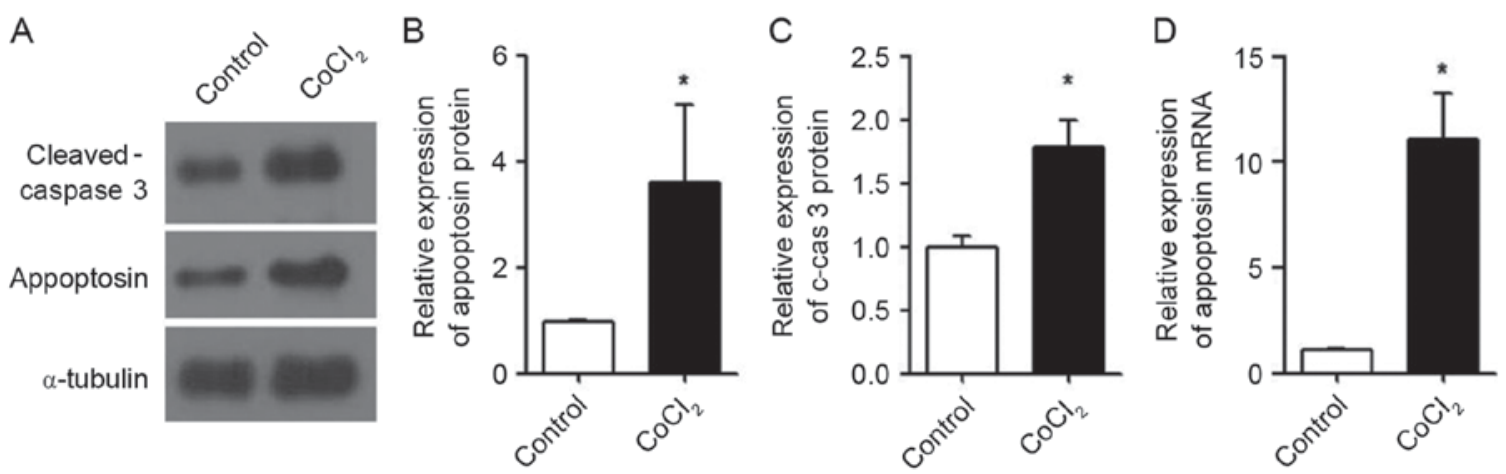

Figure 2. $\mathrm{CoCl}_{2}$ promotes the expression of appoptosin in MIN6 cells. (A) Representative western blot images demonstrating that protein expression levels of appoptosin and cleaved-caspase 3 were enhanced following $\mathrm{CoCl}_{2}$ treatment in MIN6 cells. The relative expression levels of (B) appoptosin and (C) cleaved-caspase 3 were quantified by densitometric analysis. (D) mRNA expression levels of appoptosin were increased following $\mathrm{CoCl}_{2}$ treatment. Each experiment was repeated three times. ${ }^{*} \mathrm{P}<0.05$ vs. control group. $\mathrm{CoCl}_{2}$, cobalt chloride; c-cas 3 , cleaved-caspase 3.

on autoradiography film (Kodak, Rochester, NY, USA). ImageJ (Java 1.8.0_112) was used for densitometric analysis.

Reverse transcription-quantitative polymerase chain reaction $(R T-q P C R)$. Total RNA in MIN6 cells was extracted using TRIzol reagent (Tiangen Biotech, Beijing, China) and was reverse transcribed into cDNA using Quant One Step RT-PCR kit (Tiangen Biotech). FastFire qPCR PreMix kits $\left(\mathrm{SYBR}^{\circledR}{ }^{\circledR}\right.$-Green) were purchased from Tiangen Biotech. The following thermocycling conditions were used: $95^{\circ} \mathrm{C}$ for $3 \mathrm{~min}$; 32 cycles of $95^{\circ} \mathrm{C}$ for $10 \mathrm{sec}, 60^{\circ} \mathrm{C}$ for $10 \mathrm{sec}, 72^{\circ} \mathrm{C}$ for $25 \mathrm{sec}$ and $72^{\circ} \mathrm{C}$ for $5 \mathrm{~min}$. Quantitative PCR was performed on a Roche instrument (LightCycler ${ }^{\circledR} 480$, Roche Diagnostics) and each experiments wererepeated in triplicate. The primers used in the study were as follows: Appoptosin forward, 5'-CGTCCC CAGTGATCGAGAAG-3' and reverse, 5'-GCAGACGGGTTT TGAGGAGA-3'; and $\beta$-actin forward 5'-CCCAAAGCTAAC CGGGAGAAG-3' and reverse 5'-GACAGCACCGCCTGG ATAG-3' (25).

Statistical analysis. All experimental results were analyzed using Student's t-test or one-way analysis of variance followed by Tukey's honest significant difference test. The results are presented as the mean \pm standard error. $\mathrm{P}<0.05$ was considered to indicate a statistically significant difference. All results were analyzed using GraphPad Prism version 5.0 software (GraphPad Software, Inc., La Jolla, CA, USA).

\section{Results}

$\mathrm{CoCl}_{2}$ induces apoptosis in MIN6 cells. Hypoxia is considered to be one of the leading causes of apoptosis $(26,27)$. In the present study, MIN6 cells were cultured in 24- or 96-well plates. The next day, $400 \mu \mathrm{M} \mathrm{CoCl}_{2}$ was added to induce cell apoptosis. The viability of the MIN6 cells was measured using CCK- 8 kits. Apoptosis was detected using a TUNEL assay. Following $\mathrm{CoCl}_{2}$ treatment, apoptosis was promoted (Fig. 1A) and the number of TUNEL-positive cells was quantified (Fig. 1B). Compared with the control, the viability of the MIN6 cells was significantly decreased following $\mathrm{CoCl}_{2}$ treatment (Fig. 1C).

$\mathrm{CoCl}_{2}$ induces overexpression of appoptosin and activation of caspase 3 in MIN6 cells. After confirming that $\mathrm{CoCl}_{2}$ induced apoptosis in MIN6 cells, the expression levels of intracellular appoptosin were determined. The results demonstrated that the protein expression levels of appoptosin (Fig. 2A and B) and cleaved-caspase 3 (Fig. 2A and C) in MIN6 cells were significantly increased following treatment with $\mathrm{CoCl}_{2}$. Additionally, the mRNA expression levels of appoptosin were increased by $\mathrm{CoCl}_{2}$ treatment in MIN6 cells compared with the control (Fig. 2D). 
A

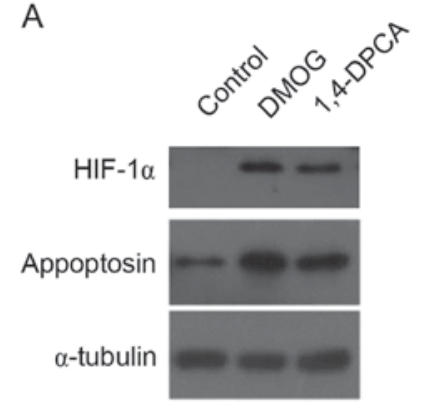

C

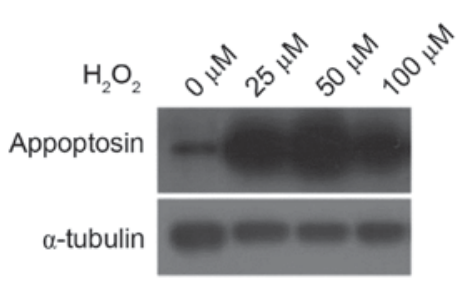

B

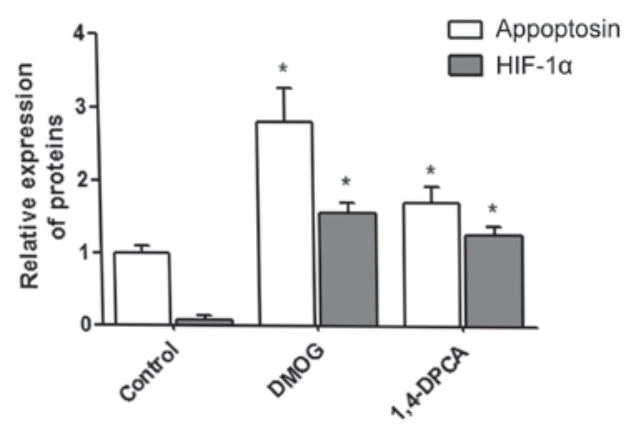

D

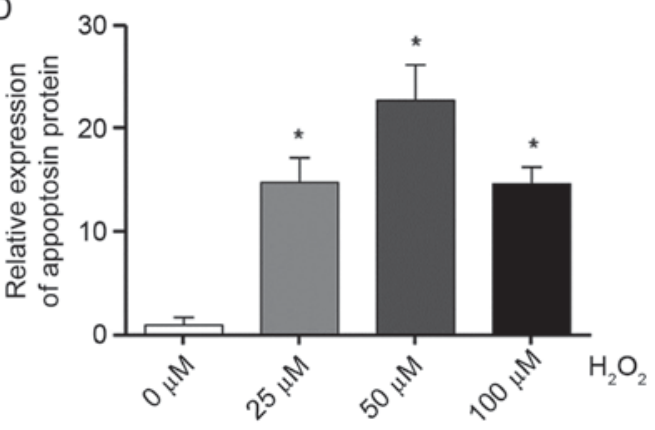

Figure 3. HIF-1 $\alpha$ and reactive oxygen species promote appoptosin expression in MIN6 cells. DMOG and 1,4-DPCA were used to treat MIN6 cells for $24 \mathrm{~h}$. (A) Representative western blot images for appoptosin and HIF-1 $\alpha$ protein expression in control, DMOG and 1,4-DPCA groups. (B) Protein expression levels of appoptosin and HIF-1 $\alpha$ in control, DMOG and 1,4-DPCA groups were quantified by densitometric analysis. (C) Representative western blot images for appoptosin protein expression in cells treated with 0-100 $\mu \mathrm{M} \mathrm{H}_{2} \mathrm{O}_{2}$. (D) Protein expression levels of appoptosin in cells treated with 0-100 $\mu \mathrm{M} \mathrm{H} \mathrm{H}_{2} \mathrm{O}_{2}$ were quantified by densitometric analysis. Each experiment was repeated three times. " $\mathrm{P}<0.05$ vs. corresponding control group. HIF-1 $\alpha$, hypoxia inducible factor-1 $\alpha$; DMOG, dimethyloxaloylglycine; 1,4-DPCA, 1,4-dihydrophenonthrolin-4-1-3-carboxylic acid; $\mathrm{H}_{2} \mathrm{O}_{2}$, hydrogen peroxide.

A

TUNEL

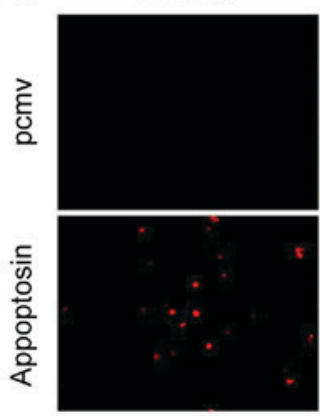

C

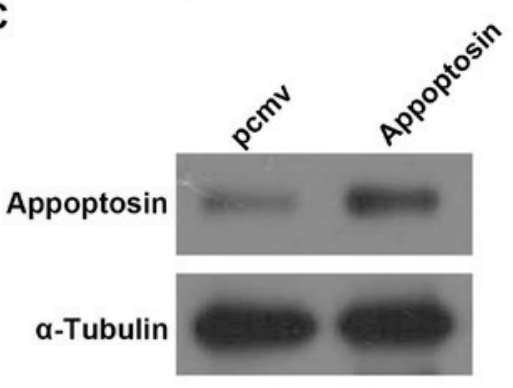

DAPI
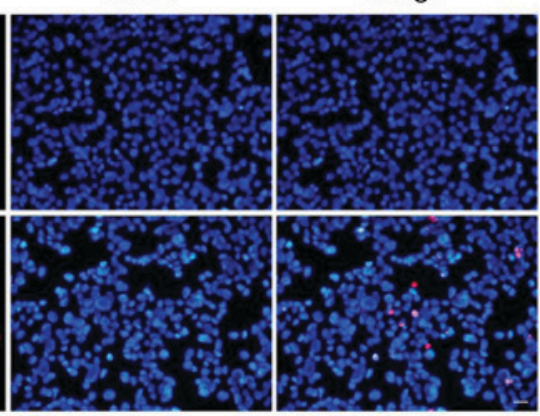

D

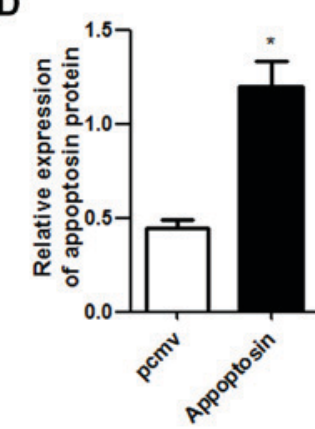

B
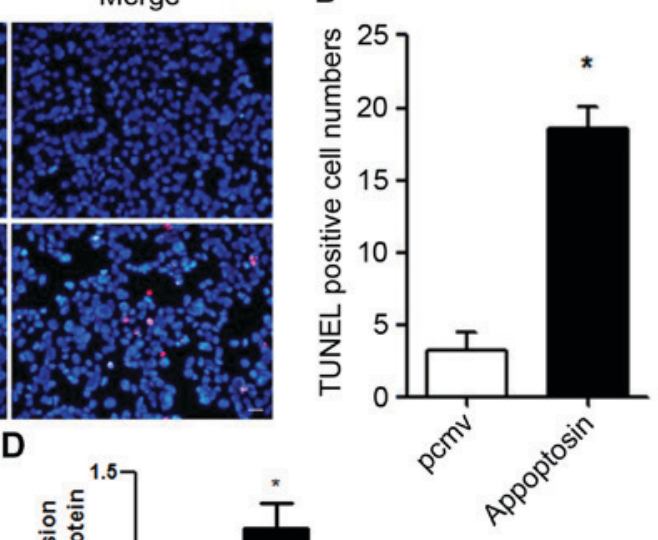

Figure 4. Overexpression of appoptosin induced apoptosis of MIN6 cells. (A) Representative images of TUNEL staining in appoptosin overexpression and pcmv groups. Magnification, $x 400$. Scale bar=25 $\mu \mathrm{m}$ (B) Quantification of the number of TUNEL-positive cells. The expression of appoptosin in MIN6 cells was measured after transfection $24 \mathrm{~h}(\mathrm{C})$. Protein expression levels of appoptosin in pcmv and appoptosin groups were quantified by densitometric analysis (D). Each experiment was repeated three times. ${ }^{*} \mathrm{P}<0.05$ vs. pcmv group. Pcmv, empty vector group; TUNEL, terminal deoxynucleotidyl transferase dUTP nick-end labeling.

$H I F-1 a$ and reactive oxygen species (ROS) promote the expression of appoptosin. It is thought that the primary function of $\mathrm{CoCl}_{2}$ in cells is the inhibition of HIF-1a degradation via the inhibition of prolyl hydroxylases (28). Therefore, the present study determined whether HIF-1a increased the expression levels of appoptosin. DMOG and 1,4-DPCA 
A
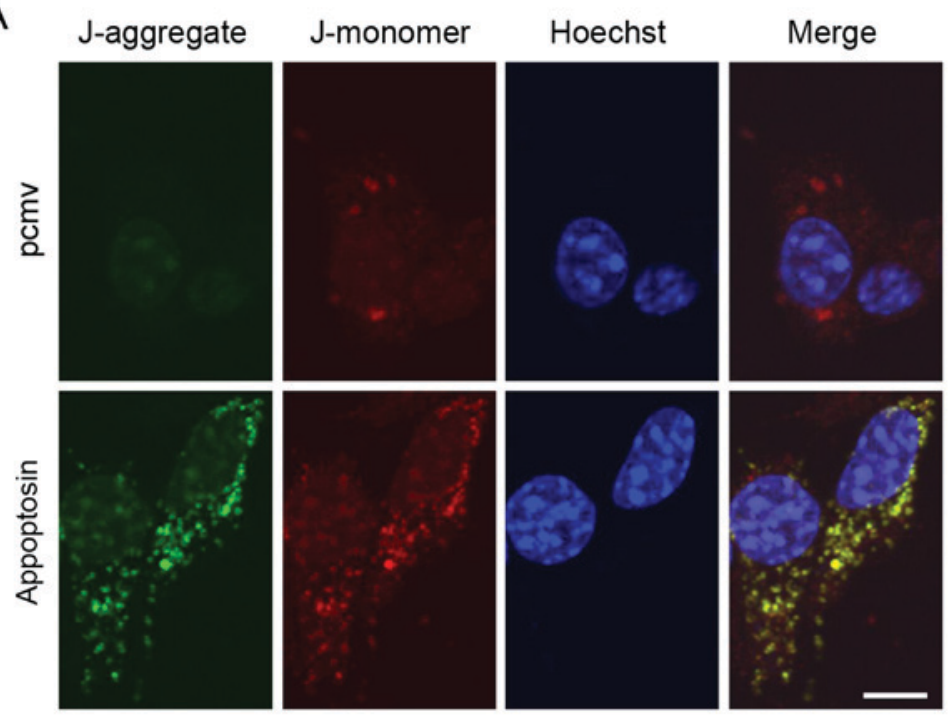

B
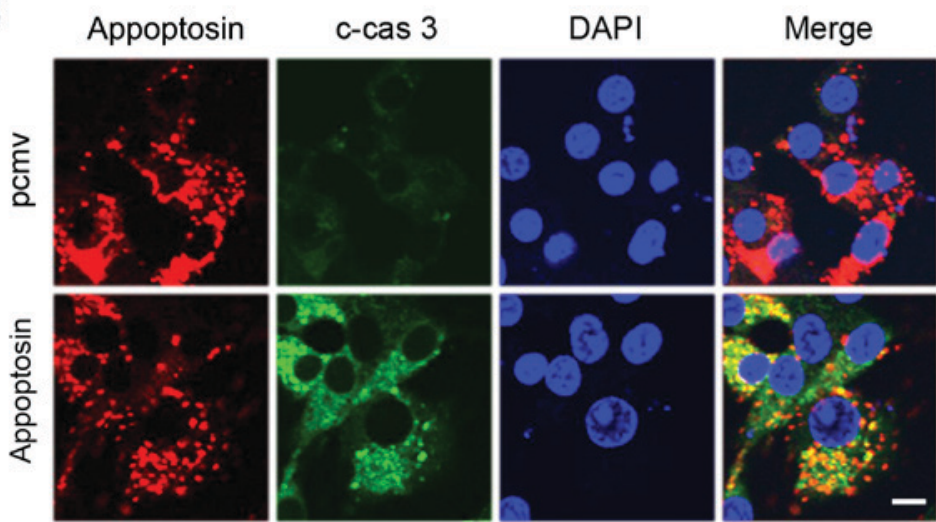

Figure 5. Overexpression of appoptosin induced mitochondrial damage and activation of caspase 3. Overexpression of appoptosin induced (A) mitochondrial damage and (B) activation of caspase 3. Magnification of (A), x600 and (B), x400. Scale bar=10 $\mu \mathrm{m}$. Each experiment was repeated three times. c-cas 3 , cleaved-caspase 3. Pcmv, empty vector group.

were used to stabilize the cellular HIF-1a protein (20), and they significantly enhanced HIF-1a and appoptosin protein expression levels in MIN6 cells compared with the control group (Fig. $3 \mathrm{~A}$ and $\mathrm{B}$ ). In addition, $\mathrm{CoCl}_{2}$ is reported to induce the expression of cellular ROS (29). Therefore, hydrogen peroxide $\left(\mathrm{H}_{2} \mathrm{O}_{2}\right)$ was used in the present study to generate ROS in MIN6 cells. The results demonstrated that concentrations of 25,50 and $100 \mu \mathrm{M} \mathrm{H}_{2} \mathrm{O}_{2}$ significantly increased the expression levels of the appoptosin protein compared with the $0 \mu \mathrm{M}$ group (Fig. $3 \mathrm{C}$ and D). Therefore, $\mathrm{CoCl}_{2}$ may increase appoptosin expression by inducing HIF-1a and cellular ROS.

Overexpression of appoptosin induces apoptosis in MIN6 cells. As the protein and mRNA expression levels of appoptosin in MIN6 cells were determined following $\mathrm{CoCl}_{2}$ treatment, the present study evaluated whether overexpression of appoptosin induced apoptosis in MIN6 cells. The results revealed that high expression levels of appoptosin increased apoptosis in MIN6 cells (Fig. 4A and B). These results indicate that a high expression of appoptosin in MIN6 cells may reduce cell viability. The expression of appoptosin in MIN6 cells was significantly increased after transfection (Fig. 4C and D).
Overexpression of appoptosin induces mitochondrial damage in MIN6 cells. As appoptosin is a mitochondrial protein, the mitochondrial membrane potential was measured by using a JC-1 staining dye after overexpression of appoptosin in MIN6 cells. The results demonstrated that high expression of appoptosin increased mitochondrial damage (Fig. 5A). Stronger green staining (J-aggregate) indicated higher levels of mitochondrial damage. Previous researchers reported that appoptosin induced apoptosis via activation of the caspase pathway (10). The results of the current study also demonstrated that overexpression of appoptosin increased the levels of cellular cleaved-caspase 3 (Fig. 5B). Additionally, overexpressed appoptosin co-localized with cleaved-caspase 3 in MIN6 cells (Fig. 5B).

Inhibiting appoptosin partially restores the viability of MIN6 cells. The expression of appoptosin protein was reduced by siRNA in MIN6 cells (Fig. 6A and B). The viability of MIN6 cells treated with $\mathrm{CoCl}_{2}$ after silencing of appoptosin was determined by a CCK- 8 assay. The results demonstrated that, in the presence of $\mathrm{CoCl}_{2}$, silencing of appoptosin enhanced the cell viability of MIN6 cells compared with the $\mathrm{NC}+\mathrm{CoCl}_{2}$ group (Fig. 6C). In conclusion, these results indicate that $\mathrm{CoCl}_{2}$ induced the expression of appoptosin, and that overexpression 
A

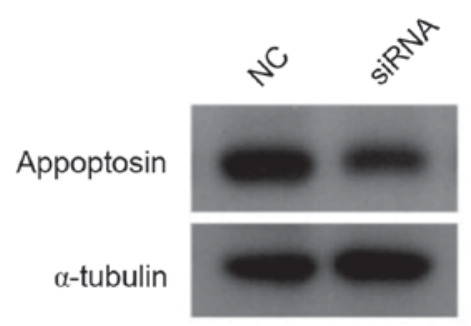

B

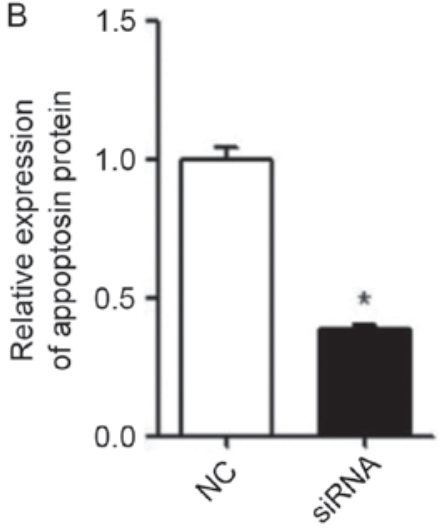

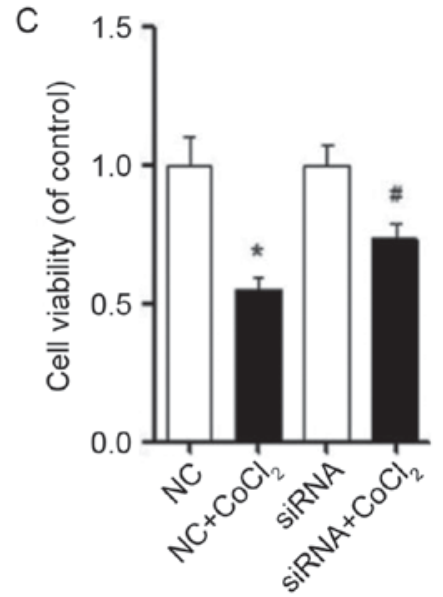

Figure 6. Inhibition of appoptosin partially restores the viability of MIN6 cells. (A) Representative western blot image for the protein expression of appoptosin following transfection with appoptosin-specific siRNA. (B) Protein expression levels of appoptosin were quantified by densitometric analysis. (C) Cell viability was determined following appoptosin knockdown and treatment with $\mathrm{CoCl}_{2}$. Each experiment was repeated three times. "P<0.05 vs. $\mathrm{NC}$ group; ${ }^{\text {"}} \mathrm{P}<0.05$ vs. $\mathrm{NC}+\mathrm{CoCl}_{2}$ group. siRNA, Small interfering RNA; $\mathrm{CoCl}_{2}$, cobalt chloride; $\mathrm{NC}$, negative control.

of appoptosin led to mitochondrial damage, while inhibition of appoptosin expression improved the viability of MIN6 cells when exposed to $\mathrm{CoCl}_{2}$.

\section{Discussion}

In the current study, it was demonstrated that the expression levels of appoptosin in MIN6 cells was increased following $\mathrm{CoCl}_{2}$ treatment. In addition, HIF-1 $\alpha$ and ROS increased appoptosin protein expression, and overexpression of appoptosin induced mitochondrial damage and increased cleaved-caspase 3 expression. Inhibition of appoptosin partially recovered the viability of MIN6 cells. The results of the present study indicated that high expression levels of appoptosin may induce mitochondrial damage and apoptosis in pancreatic $\beta$-cells. However, the expression of appoptosin in diabetes or islets remains unknown. Further research is required to investigate the role of appoptosin in diabetes, particularly in islet transplantation research.

The primary role of pancreatic $\beta$-cells is the secretion of insulin when glucose levels are high, which requires a large amount of energy from oxidative phosphorylation; thus, pancreatic $\beta$-cells are frequently exposed to hypoxia and oxidative stress (30-32). In addition, high glucose levels consume higher levels of oxygen in islets (33). Reducing the extent of damage to pancreatic $\beta$-cells may help provide an improved treatment strategy for type 1 and type 2 diabetes. In the present study, it was observed that appoptosin was sensitive to hypoxia and cellular ROS. The current study determined the effects of chemical induction of HIF-1 $\alpha$ expression on appoptosin expression. However, further research is required to validate these findings using HIF-1 $\alpha$ overexpression or induction under actual hypoxic conditions $\left(\mathrm{O}_{2}\right.$ levels $\left.<1 \%\right)$. In addition, overexpression of appoptosin induced mitochondrial damage and caspase 3 activation. The results of the present study are consistent with those of previous studies performed in neuronal and 293T cells $(10,13)$. Thus, it was hypothesized that the expression of appoptosin increases during diabetes due to factors such as hypoxia and oxidative stress. The present study indicated that inhibiting the expression of appoptosin in pancreatic $\beta$-cells may promote cell viability upon transplantation and provide a novel approach for treating diabetes. A limitation of the present study is that only one siRNA was used. Although its specificity has been confirmed in a previous study (10), further research is required to validate and exclude off-targeting effects of the siRNA used.

Appoptosin is a major regulator in neuronal disease and health. However, the role and involvement of appoptosin in other diseases remains unclear. Although the present study confirmed that the expression of appoptosin was increased in MIN6 cells following treatment with $\mathrm{CoCl}_{2}$ and $\mathrm{H}_{2} \mathrm{O}_{2}$, the appoptosin promoter and the proteins interacting with the promoter are yet to be identified, and are the focus of future investigation. Identifying the promoter and upstream regulators of appoptosin will aid in more effective inhibition of its function and accelerating the degradation of appoptosin may also protect pancreatic $\beta$-cells.

Appoptosin is an endometrial mitochondrial protein that is closely associated with mitochondrial function. Insulin secretion primarily depends on mitochondria for its energy requirement. Thus, appoptosin may be associated with insulin secretion in pancreatic $\beta$-cells. The association between appoptosin and insulin secretion warrants further investigation.

\section{Acknowledgements}

The authors thank Professor Zhang (Institute of Neuroscience, Xiamen University, Xiamen, China) for providing the plasmids.

\section{Funding}

The present study was supported by grants from the National Natural Science Foundation to SY (grant no. 30973912), XL (grant no. 81570770), CH (grant no. 81673661) and SL (grant no. 81270901), the Key Project of Fujian Provincial Science and Technology Planning programs (grant no. 2012D60) and the Xiamen Innovation Program for Outstanding Youth Scientist (grant no. 2011S0446) to SL, Xiamen Science and Technology Bureau (Xiamen Research Platform for Systems Biology of Metabolic Disease, grant no. 3502Z20100001). 


\section{Availability of data and materials}

All data generated or analyzed during the present study are included in this published article.

\section{Authors' contributions}

TW, XL, SL and SY conceived and designed the study. TW, WW, HAAM, CH, LL, QY, HY and CY performed the experiments. TW and HAAM wrote the paper. XL, SL and SY reviewed and edited the manuscript. SY agrees to be accountable for all aspects of the work. All authors read and approved the manuscript.

\section{Ethics approval and consent to participate}

Not applicable.

\section{Consent for publication}

Not applicable.

\section{Competing interests}

The authors declare that they have no competing interests.

\section{References}

1. Chiang JL, Kirkman MS, Laffel LM and Peters AL; Type 1 Diabetes Sourcebook Authors: Type 1 diabetes through the life span: A position statement of the American Diabetes Association. Diabetes care 37: 2034-2054, 2014.

2. Xu Y, Wang L, He J, Bi Y, Li M, Wang T, Wang L, Jiang Y, Dai M, Lu J, et al: Prevalence and control of diabetes in Chinese adults. Jama 310: 948-959, 2013.

3. Atkinson MA, Eisenbarth GS and Michels AW: Type 1 diabetes. Lancet 383: 69-82, 2014.

4. Ryan EA, Lakey JR, Rajotte RV, Korbutt GS, Kin T, Imes S, Rabinovitch A, Elliott JF, Bigam D, Kneteman NM, et al: Clinical outcomes and insulin secretion after islet transplantation with the Edmonton protocol. Diabetes 50: 710-719, 2001.

5. Bruni A, Gala-Lopez B, Pepper AR, Abualhassan NS and Shapiro AJ: Islet cell transplantation for the treatment of type 1 diabetes: Recent advances and future challenges. Diabetes Metab Syndr Obes 7: 211-223, 2014

6. Shapiro AJ,Lakey JR, Ryan EA, Korbutt GS, Toth E, Warnock GL, Kneteman NM and Rajotte RV: Islet transplantation in seven patients with type 1 diabetes mellitus using a glucocorticoid-free immunosuppressive regimen. N Engl J Med 343: 230-238, 2000.

7. Ludwig B, Rotem A, Schmid J, Weir GC, Colton CK, Brendel MD, Neufeld T, Block NL, Yavriyants K, Steffen A, et al: Improvement of islet function in a bioartificial pancreas by enhanced oxygen supply and growth hormone releasing hormone agonist. Proc Natl Acad Sci 109: 5022-5027, 2012.

8. Ryan EA, Paty BW, Senior PA, Bigam D, Alfadhli E, Kneteman NM, Lakey JR and Shapiro AM: Five-year follow-up after clinical islet transplantation. Diabetes 54: 2060-2069, 2005.

9. Cheng CW, Villani V, Buono R, Wei M, Kumar S, Yilmaz OH, Cohen P, Sneddon JB, Perin L and Longo VD: Fasting-mimicking diet promotes ngn 3 -driven $\beta$-cell regeneration to reverse diabetes. Cell 168: 775-788.e712, 2017.

10. Zhang H, Zhang YW, Chen Y, Huang X, Zhou F, Wang W, Xian B, Zhang X, Masliah E, Chen Q, et al: Appoptosin is a novel pro-apoptotic protein and mediates cell death in neurodegeneration. J Neurosci 32: 15565-15576, 2012.

11. Zhang C, Shi Z, Zhang L, Zhou Z, Zheng X, Liu G, Bu G, Fraser PE, Xu H and Zhang YW: Appoptosin interacts with mitochondrial outer-membrane fusion proteins and regulates mitochondrial morphology. J Cell Sci 129: 994-1002, 2016.

12. Zhao Y, Tseng IC, Heyser CJ, Rockenstein E, Mante M, Adame A, Zheng Q, Huang T, Wang X, Arslan PE, et al: Appoptosin-mediated caspase cleavage of tau contributes to progressive supranuclear palsy pathogenesis. Neuron 87: 963-975, 2015.
13. Zheng KM, Zhang J, Zhang $\mathrm{Cl}$, Zhang $\mathrm{YW}$ and Chen $\mathrm{XC}$ : Curcumin inhibits appoptosin-induced apoptosis via upregulating heme oxygenase-1 expression in SH-SY5Y cells. Acta Pharmacol Sin 36: 544-552, 2015.

14. PIRET JP, Mottet D, Raes M and Michiels C: $\mathrm{CoCl} 2$, a chemical inducer of hypoxia-inducible factor-1 and hypoxia reduce apoptotic cell death in hepatoma cell line HepG2. Ann N Y Acad Sci 973: 443-447, 2002.

15. Sano M, Minamino T, Toko H, Miyauchi H, Orimo M, Qin Y, Akazawa H, Tateno K, Kayama Y, Harada M, et al: p53-induced inhibition of Hif-1 causes cardiac dysfunction during pressure overload. Nature 446: 444, 2007.

16. Yuan Y, Hilliard G, Ferguson T and Millhorn DE: Cobalt inhibits the interaction between hypoxia-inducible factor-alpha and von Hippel-Lindau protein by direct binding to hypoxia-inducible factor-alpha. J Biol Chem 278: 15911-15916, 2003.

17. Jaakkola P, Mole DR, Tian YM, Wilson MI, Gielbert J, Gaskell SJ, von Kriegsheim A, Hebestreit HF, Mukherji M, Schofield CJ, et al: Targeting of HIF- $\alpha$ to the von Hippel-Lindau Ubiquitylation Complex by O2-Regulated Prolyl Hydroxylation. Science 292: 468-472, 2001.

18. Bruick RK and Mcknight SL: A conserved family of prolyl-4-Hydroxylases that modify HIF. Science 294: 1337-1340, 2001.

19. Ivan M, Kondo K, Yang H, Kim W, Valiando J, Ohh M, Salic A, Asara JM, Lane WS and Kaelin WG Jr: HIFalpha targeted for VHL-mediated destruction by proline hydroxylation: Implications for O2 sensing. Science 292: 464-468, 2001.

20. Cheung EC, Ludwig RL and Vousden KH: Mitochondrial localization of TIGAR under hypoxia stimulates HK2 and lowers ROS and cell death. Proc Natl Acad Sci USA 109: 20491-20496, 2012.

21. Franklin TJ, Morris WP, Edwards PN, Large MS and Stephenson R: Inhibition of prolyl 4-hydroxylase in vitro and in vivo by members of a novel series of phenanthrolinones. Biochem J 353: 333-338, 2001.

22. Banerji B, Conejogarcia A, Mcneill LA, McDonough A, Buck MR, Hewitson KS, Oldham NJ and Schofield CJ: The inhibition of factor inhibiting hypoxia-inducible factor $(\mathrm{FIH})$ by beta-oxocarboxylic acids. Chem Commun (Camb): 5438-5440, 2005.

23. Litmanovitz I, Bar-Yoseph F, Lifshitz Y, Davidson K, Eliakim A, Regev RH and Nemet D: Reduced crying in term infants fed high beta-palmitate formula: A double-blind randomized clinical trial. BMC Pediatr 14: 152, 2014.

24. Li Z, Shangguan Z, Liu Y, Wang J, Li X, Yang S and Liu S: Puerarin protects pancreatic $\beta$-cell survival via PI3K/Akt signaling pathway. J Mol Endocrinol 53: 71-79, 2014.

25. Livak KJ and Schmittgen TD: Analysis of relative gene expression data using real-time quantitative PCR and the 2(-Delta Delta C(T)) method. Methods 25: 402-408, 2001.

26. Zheng X, Zheng X, Wang X, Ma Z, Gupta Sunkari V, Botusan I, Takeda T, Björklund A, Inoue M, Catrina SB, et al: Acute hypoxia induces apoptosis of pancreatic $\beta$-cell by activation of the unfolded protein response and upregulation of CHOP. Cell Death Dis 3: e322, 2012.

27. Fang Y, Zhang Q, Tan J, Li L, An X and Lei P: Intermittent hypoxia-induced rat pancreatic $\beta$-cell apoptosis and protective effects of antioxidant intervention. Nutr Diabetes 4: e131, 2014.

28. Yildirim Ö: The effect of vitamin $C$ and cobalt supplementation on antioxidant status in healthy and diabetic rats. African $\mathrm{J}$ Biotechnol 8,2009.

29. Leonard SS, Harris GK and Shi X: Metal-induced oxidative stress and signal transduction. Free Radical Biol Med 37: 1921-1942, 2004.

30. Sato Y, Endo H, Okuyama H, Takeda T, Iwahashi H, Imagawa A, Yamagata K, Shimomura I and Inoue M: Cellular hypoxia of pancreatic beta-cells due to high levels of oxygen consumption for insulin secretion in vitro. J Biol Chem 286: 12524-12532, 2011.

31. Carlsson PO, Liss P, Andersson A and Jansson L: Measurements of oxygen tension in native and transplanted rat pancreatic islets. Diabetes 47: 1027-1032, 1998.

32. Cantley J, Selman C, Shukla D, Abramov AY, Forstreuter F, Esteban MA, Claret M, Lingard SJ, Clements M, Harten SK, et al: Deletion of the von Hippel-Lindau gene in pancreatic beta cells impairs glucose homeostasis in mice. J Clin Invest 119: 125-135, 2009.

33. Wang W,UpshawL,StrongDM,RobertsonRPandReems J: Increased oxygen consumption rates in response to high glucose detected by a novel oxygen biosensor system in non-human primate and human islets. J Endocrinol 185: 445-455, 2005.

This work is licensed under a Creative Commons Attribution-NonCommercial-NoDerivatives 4.0 International (CC BY-NC-ND 4.0) License. 